\title{
Fusarium solani on Soybean Roots: Nomenclature of the Causal Agent of Sudden Death Syndrome and Identity and Relevance of $F$. solani form B
}

\author{
K. W. Roy, Professor, Department of Entomology and Plant Pathology, Mississippi State University, Mississippi \\ State 39762
}

\begin{abstract}
Roy, K. W. 1997. Fusarium solani on soybean roots: Nomenclature of the causal agent of sudden death syndrome and identity and relevance of $F$. solani form B. Plant Dis. 81:259-266.

Two morphological forms of Fusarium solani pathogenic on soybean, forms A and B, were further characterized and distinguished from other fungi. Questions regarding their identity were addressed. Soybean plants grown in the field and in a growth chamber were inoculated with Fusarium solani form A and F. solani f. sp. phaseoli. F. solani form A incited leaf symptoms typical of sudden death syndrome; $F$. solani f. sp. phaseoli did not. It was concluded that the two fungi are different and distinguishable on the basis of host specialization and the types of symptoms they incite on soybean. $F$. solani form A, the causal agent of sudden death syndrome, was designated F. solani (Mart.) Sacc. f. sp. glycines form. nov. Cultural and morphological characteristics of $F$. solani form B, the cause of seedling disease and root rot of soybean, and Plectosphaerella cucumerina were compared to determine the validity of a report indicating that they were conspecific. Results demonstrated that $F$. solani form B and P. cucumerina are distinctly different and not conspecific. The relevance of identifying and recognizing the two $F$. solani forms as separate and distinct members of the $F$. solani pathogen complex on soybean is discussed.
\end{abstract}

Additional keywords: Fusarium tabacinum, Heterodera glycines, host range

In 1988, Koch's postulates were completed with Fusarium solani (Mart.) Sacc. as the causal agent of seedling disease and root rot of older soybean (Glycine max (L.) Merr.) plants (19). Later, this same fungus, then called strain $B$, and an apparently different strain of $F$. solani, then called strain A, were found associated with roots of soybean plants symptomatic for sudden death syndrome (SDS). Through comparative pathogenicity tests, only strain A was found capable of inciting all the symptoms of SDS. Upon completion of Koch's postulates for SDS, a brief report was published in 1988 by Roy et al. (33), followed by comprehensive reports in 1989 by Roy et al. (34-36) and Rupe (40). In the 1989 reports by Roy et al. (34-36), the SDS causal agent was designated a morphological form of $F$. solani, form A. To distinguish the two fungi and ensure that the $F$. solani seedling/root rot pathogen would not be confused with the causal agent of SDS, the seedling/root rot fungus also was designated a morphological form, $F$. solani

Corresponding author: K. W. Roy

E-mail: sunil@ra.msstate.edu

Published with the approval of the Director, Mississippi Agricultural and Forestry Experiment Station, as Journal Series Paper No. J-8865.

Accepted for publication 14 January 1997.

Publication no. D-1997-0204-04R

(C) 1997 The American Phytopathological Society form B (FSB). That same year, when Rupe (40) also reported completion of Koch's postulates for SDS, he referred to the causal fungus as a blue-pigmented strain of $F$. solani that is considered to be the same as FSA (41; J. C. Rupe, personal communication).

Although cultural and morphological characteristics distinguishing FSA and FSB were described (34-36) and illustrated (34) in 1989, there now exists doubt regarding the identity of these two fungi and confusion regarding the diseases they incite. In one paper (50), a study by Killebrew et al. (19) was cited to document that SDS had yield-reducing potential, although the article by Killebrew et al. dealt solely with the F. solani later designated FSB (34-36). In other papers, the study by Killebrew et al. was cited to support observations on variability in the SDS causal agent (51) and to document the production of SDS leaf symptoms on artificially inoculated plants in the greenhouse (52). Recent evidence from rDNA sequence and RFLP analyses (28) of several species within the $F$. solani complex led to the conclusion that $F$. solani f. sp. phaseoli (Burkholder) W.C. Snyder $\&$ H.N. Hans., the cause of root rot of bean (Phaseolus vulgaris L.) (20), was a phylogenetically distinct species comprised of both $F$. solani f. sp. phaseoli and FSA. On that basis, and because $F$. solani f. sp. phaseoli was described before FSA (48), $F$. solani f. sp. phaseoli was declared the causal agent of SDS, which in effect synonymized these two fungi. However, al- though it was concluded that $F$. solani $\mathrm{f}$. sp. phaseoli was the cause of SDS, soybean plants were not inoculated with $F$. solani f. sp. phaseoli to determine whether this organism would incite symptoms of SDS (28). Thus, a critical question left unanswered is whether $F$. solani f. sp. phaseoli and FSA are similar or dissimilar on the basis of physiological (host) specialization. Clearly, F. solani f. sp. phaseoli cannot be considered the causal agent of SDS of soybean, or a synonym of FSA, unless it incites all the symptoms characteristic of SDS, as is well documented for FSA (22,23,34-36). The major symptoms of SDS are root rot, crown necrosis, vascular discoloration of roots and stems, interveinal chlorosis and necrosis of leaves, premature defoliation, and flower and pod abortion $(23,34,36,37,40,43,44)$.

The absence of reports of FSB isolation from roots of SDS-symptomatic plants by other researchers is unexpected given that the frequency of isolation of FSB from roots of such plants is usually as high as or higher than that of FSA $(23,32,34-36,39)$. This suggests that FSB is not acknowledged as being separate and distinct from the SDS causal fungus. Recently, $F$. solani isolates from soybean roots that did not produce a blue pigment and produced both macroconidia and microconidia were observed (41). However, although these isolates were similar to $\operatorname{FSB}(34,35)$, the authors (41) did not identify them as FSB. In another study, FSB and Plectosphaerella cucumerina (Lindf.) W. Gams, a perithecial ascomycete, were found to be conspecific based on results of molecular analyses (28). However, this was not corroborated by a direct comparison of the cultural and morphological characteristics of these two fungi, nor was literature describing (34-36) and illustrating (34) FSB cited in that study. Apparently, this claim of conspecificity was accepted by Achenbach et al. (3), since they included $P$. $c u$ cumerina in tests with $F$. solani. Inexplicably, they made no reference to FSB or its association with $P$. cucumerina. In fact, their data conflict with the claim of conspecificity (28). Moreover, the conidial stage of $P$. cucumerina is not a Fusarium (31), although it was once thought to be $F$. tabacinum (Van Beymar) W. Gams $(4,7,29,56)$.

Questions regarding the identity of FSA and FSB, the diseases they incite, and the relationship among these fungi and other 
strains of $F$. solani on soybean roots and other crops need to be resolved. Unless they are resolved, it is likely that confusion will grow, and with it a confounding of the literature. The main purpose of this report is to address those questions. It is shown that when isolates of FSA and $F$. solani $\mathrm{f}$. sp. phaseoli are inoculated onto soybean, only FSA incites the leaf symptoms characteristic of SDS: thus, FSA is distinct from F. solani f. sp. phaseoli. FSA is further characterized culturally and morphologically, and a forma specialis designation is proposed for it. In addition, the identity of FSB as a form of $F$. solani is reaffirmed on the basis of cultural and morphological characteristics, and the importance of recognizing FSB as a pathogenic member of the $F$. solani complex on soybean is discussed.

An issue concerning the identity of Nectria haematococca Berk. \& Broome and its connection to the SDS causal agent $(1,2,28)$ is outside the scope of the present study and should be addressed by those directly involved in initially making that connection in 1989 (1).

\section{MATERIALS AND METHODS}

Sources and descriptions of $F$. solani and $P$. cucumerina isolates used in this study are listed in Table 1. All isolates were stored at ca. $5^{\circ} \mathrm{C}$ in slants of potato-dextrose agar prior to use.

Comparative pathogenicity tests with FSA and $F$. solani f. sp. phaseoli. Monosporic isolates of FSA and $F$. solani f. sp. phaseoli were obtained using the method of Booth (4). In preliminary tests, isolates of FSA and F. solani f. sp. phaseoli were wound-inoculated on soybean and green bean seedlings, respectively, and the reisolates from necrotic tissue then were used in main tests. Inocula for all tests were prepared by growing the fungi on sterilized sorghum seeds in $500 \mathrm{~cm}^{3}$ flasks. Moist sorghum seeds were autoclaved twice for $20 \mathrm{~min}$, after which mycelial plugs from the isolates were separately and aseptically transferred to and intermixed with cooled seeds. Cultures were incubated under ordinary light conditions in the laboratory and were periodically shaken to obtain uniform distribution of inoculum during 3 weeks of incubation at $25^{\circ} \mathrm{C}$.

FSA isolate $91-7$ and $F$. solani f. sp. phaseoli isolates 13719 and 18006 from the American Type Culture Collection (ATCC) were used in the first two of a total of four pathogenicity tests. In test 1 , soybean cv. Asgrow 4715 was planted at the Mississippi State University Plant Science Research Center on 1 May 1992, in each of four replicates (rows). From seven seedlings per replicate, soil was pulled back to expose the taproot, ca. $0.4 \mathrm{~g}$ of infested sorghum seeds were uniformly distributed around and in contact with the taproot about $2 \mathrm{~cm}$ below the soil line, and the soil was replaced. Equal numbers of control seedlings were treated with sterilized sorghum seeds only. At the time of inoculation, seedlings were in the V4 stage of growth (9). Following inoculation, the soil around test plants was watered to help prevent inoculum desiccation, but irrigation was not available during the growing season. In test 2 , concurrent with test 1 , Asgrow 4715 seedlings were grown in 10$\mathrm{cm}$-diameter pots of nonsterile greenhouse

Table 1. Sources and descriptions of fungi used in this study

\begin{tabular}{|c|c|c|c|c|}
\hline Fungus isolate & Isolate no. & Source & Substrate origin & $\begin{array}{c}\text { Geographic } \\
\text { origin }\end{array}$ \\
\hline $\begin{array}{l}\text { Fusarium solani f. sp. } \\
\text { phaseoli }\end{array}$ & 13719 & $\mathrm{ATCC}^{\mathrm{x}}$ & $\begin{array}{l}\text { Phaseolus } \\
\text { vulgaris }\end{array}$ & California \\
\hline F. solani f. sp. phaseoli & 18006 & ATCC & P. vulgaris & California \\
\hline F. solani f. sp. phaseoli & 38466 & ATCC & P. vulgaris & California \\
\hline F. solani form A & IN-F2X-11A & T. S. Abney & Soybean & Indiana \\
\hline F. solani form A & $91-7$ & Author & Soybean & Kentucky \\
\hline F. solani form A & A-15 & Author & Soybean & Kentucky \\
\hline F. solani form A & A-16 & Author & Soybean & Kentucky \\
\hline F. solani form A & A-11 & Author & Soybean & Mississippi \\
\hline F. solani form A & A-12 & Author & Soybean & Mississippi \\
\hline F. solani form A & A-13 & Author & Soybean & Arkansas \\
\hline F. solani form A & A-14 & Author & Soybean & Arkansas \\
\hline F. solani form A & A-17 & Author & $\begin{array}{l}\text { Heterodera } \\
\text { glycines cyst }\end{array}$ & Arkansas \\
\hline F. solani form A & $94-1$ & Author & H. glycines cyst & Illinois \\
\hline F. solani form B & FSB-2 & Author & Soybean & Illinois \\
\hline F. solani form B & FSB-6 & Author & Soybean & Kentucky \\
\hline F. solani form B & F-465 & Author & H. glycines cyst & Mississippi \\
\hline F. solani & 46472 & ATCC & H. glycines cyst & Florida \\
\hline F. solani & 11712 & ATCC & Cucurbito pepo & California \\
\hline $\begin{array}{l}\text { Plectosphaerella } \\
\text { cucumerina }^{\mathrm{z}}\end{array}$ & IN-11P-12 & T. S. Abney & Soybean & Indiana \\
\hline P. cucumerina $^{\mathrm{z}}$ & IN-2X-11N & T. S. Abney & Soybean & Indiana \\
\hline P. cucumerina ${ }^{\mathrm{z}}$ & IN-11-12 & T. S. Abney & Soybean & Indiana \\
\hline
\end{tabular}

${ }^{x}$ American Type Culture Collection.

y Department of Botany and Plant Pathology, Purdue University, W. Lafayette, Indiana.

${ }^{\mathrm{z}}$ Determined to be P. cucumerina by O'Donnell and Gray (28).

potting soil outdoors in Starkville, Mississippi. The pots were maintained on a concrete surface. Four seedlings in the V2 stage of growth in each of four replicate pots were inoculated with each isolate as described above, and pots were arranged in a randomized complete block design. Plants were watered regularly to maintain high soil moisture, which favors infection $(23,34,40)$. In both tests, the percentage of plants with SDS leaf symptoms was determined. The tests were terminated 7 days after expression of SDS leaf symptoms on the plants that were inoculated with isolates of FSA.

In tests 3 and 4 , plants were grown in a controlled-environment growth chamber (Controlled Environment Limited, Winnipeg, Manitoba, Canada) at $25^{\circ} \mathrm{C}$ and with a 14-h photoperiod. Asgrow 4715 seedlings were grown in 10-cm-diameter plastic cups containing nonsterile greenhouse potting soil. At the V2 stage of growth, four seedlings in each of three replicates were inoculated with FSA isolate IN-F2X-11A or F. solani f. sp. phaseoli ATCC isolates 18006 and 38466 as described above. The percentage of plants with SDS leaf symptoms was determined during a 5-week incubation period, after which plants were removed from cups and examined for the presence of root necrosis. Symptoms on roots were rated as follows: $0=$ no necrosis, $1=$ slight necrosis, $2=$ moderate necrosis, $3=$ extensive necrosis, and $4=$ very severe necrosis. The presence of test fungi in symptomatic roots was determined by surface-disinfesting root tissue in $1 \%$ sodium hypochlorite $(\mathrm{NaOCl})$ for $1 \mathrm{~min}$ and plating tissue on PDA. Test 4 was a repeat of test 3 .

Cultural and morphological characteristics of FSA. To supplement the description of FSA beyond that published in 1989 (34-36) and more precisely delineate this fungus, its growth response to temperature and the range in variability of its growth rate, colony characteristics, and macroconidial dimensions were investigated.

Ten isolates from soybean roots and cysts of Heterodera glycines Ichinohe, the soybean cyst nematode (SCN) (Table 1), were grown on PDA in darkness at 20, 25, and $30^{\circ} \mathrm{C}$. In preliminary tests, relatively little growth occurred at 10,15 , or $30^{\circ} \mathrm{C}$ compared with 20 and $25^{\circ} \mathrm{C}$. Uniform 5mm-diameter cylinders of mycelium growing on PDA were transferred to the center of $9-\mathrm{cm}$ petri plates of PDA. Four test plates (replicates) each were exposed to the three temperatures for 7 days, after which two measurements of colony diameter were taken at right angles and averaged. For each temperature, the variability in average colony diameter among isolates was estimated with the standard deviation.

Observations on the variability in colony characteristics were based largely on the examination of several hundred colonies of 
FSA growing on and from surface-disinfested soybean root sections that were cultured on PDA amended with streptomycin B sulfate $(100 \mu \mathrm{g} / \mathrm{liter})$ and aureomycin ( $2 \mu \mathrm{g} / \mathrm{liter}$ ) (PDASA). The roots were obtained from SDS-symptomatic plants during disease surveys in several midwestern and southern states from 1986 to 1994. Publications from that work contain the methodology used for the assay of roots $(23,32,34-36,38)$. Observations from examining the several hundred colonies of FSA were corroborated by examination of monosporic cultures and mass transfer subcultures on PDA and PDASA. Cultures containing the root sections were incubated for 2 weeks at ca. $25^{\circ} \mathrm{C}$ under ordinary light conditions in the laboratory. Monosporic and mass transfer cultures were grown for 2 weeks under the same conditions and at ca. $25^{\circ} \mathrm{C}$ under continuous fluorescent light $\left(38 \mu \mathrm{E} \cdot \mathrm{s}^{-1} \cdot \mathrm{m}^{-2}\right)$. For comparison, isolates stored in slant cultures on PDA for 6 months to 1 year were grown under the same conditions.

The 10 isolates of FSA were grown on modified Bilay's medium (4) at $25^{\circ} \mathrm{C}$ under continuous fluorescent light (38 $\left.\mu \mathrm{E} \cdot \mathrm{s}^{-1} \cdot \mathrm{m}^{-2}\right)$. After 7 days, macroconidia were mounted in cotton blue-lactophenol, and the dimensions of 50 conidia per isolate were determined microscopically with an ocular micrometer. Variability in mean macroconidial dimensions among isolates was estimated with the standard deviation. In addition, 10 randomly selected soybean roots on which FSA was observed to be sporulating in the field were used to determine the size of macroconidia produced on the host. Subsequent to their collection $(23,38)$, the roots had been stored under

Table 2. Comparative ability of Fusarium solani form A and F. solani f. sp. phaseoli to incite symptoms of sudden death syndrome (SDS) after inoculation on soybean cv. Asgrow 4715 in a growth chamber ${ }^{\mathrm{w}}$

\begin{tabular}{|c|c|c|c|c|c|c|}
\hline Fungus & $\begin{array}{c}\text { Plants with } \\
\text { SDS leaf } \\
\text { symptoms }(\%)^{x}\end{array}$ & $\begin{array}{c}\text { Severity } \\
\text { of root } \\
\text { necrosis }^{y}\end{array}$ & \multicolumn{4}{|c|}{$\begin{array}{l}\text { were determined as described above. Each } \\
\text { treatment was replicated seven times, the } \\
\text { experiment was repeated once, and treat- }\end{array}$} \\
\hline $\begin{array}{l}\text { F. solani form A } \\
\text { (IN-F2X-11A) } \\
\text { F. solani } \mathrm{f} \text {. sp. } \\
\text { phaseoli } 38466^{\mathrm{Z}} \\
\text { F. solani } \mathrm{f} \text {. sp. }\end{array}$ & 66 & $1.6^{*}$ & \multicolumn{4}{|c|}{$\begin{array}{l}\text { Table 3. Colony diameters }(\mathrm{mm}) \text { of } 10 \text { isolates } \\
\text { of Fusarium solani form A after growth on } \\
\text { potato-dextrose agar in darkness for } 7 \text { days at } \\
\text { three different temperatures }\end{array}$} \\
\hline phaseoli $18006^{\mathrm{z}}$ & & & \multirow[b]{2}{*}{ Isolate } & \multicolumn{3}{|c|}{ Temperature $\left({ }^{\circ} \mathbf{C}\right)$} \\
\hline Control & 0 & 0.7 & & 20 & 25 & 30 \\
\hline \multicolumn{3}{|c|}{$\begin{array}{l}\text { " } \text { Average of two tests. } \\
{ }^{\mathrm{x}} \text { Symptoms often appear first as chlorotic } \\
\text { mottling, sometimes accompanied by upturn- } \\
\text { ing of leaf margins, followed by interveinal } \\
\text { chlorosis that may progress to interveinal } \\
\text { necrosis. } \\
\text { y Average of two tests. Severity ratings: } 0=\text { no } \\
\text { necrosis, } 1=\text { slight necrosis, } 2=\text { moderate } \\
\text { necrosis, } 3=\text { extensive necrosis, } 4=\text { very } \\
\text { severe necrosis. An asterisk indicates a sig- } \\
\text { nificant }(P \leq 0.05) \text { difference from the control } \\
\text { as determined by analysis of variance and the } \\
\text { LSD test. } \\
\text { z American Type Culture Collection isolates. }\end{array}$} & $\begin{array}{l}\text { IN-F2X-11 } \\
91-7 \\
\text { A-15 } \\
\text { A-16 } \\
\text { A-11 } \\
\text { A-12 } \\
\text { A-13 } \\
\text { A-14 } \\
\text { A-17 } \\
94-1 \\
\text { Mean } \\
\text { Standard } \\
\text { deviations }\end{array}$ & $\begin{array}{l}17.7 \\
17.9 \\
16.5 \\
18.8 \\
16.8 \\
19.0 \\
16.5 \\
17.8 \\
16.5 \\
17.3 \\
17.5 \\
\pm 0.9\end{array}$ & $\begin{array}{l}22.8 \\
24.8 \\
25.0 \\
23.8 \\
23.8 \\
25.8 \\
25.0 \\
24.2 \\
24.0 \\
23.6 \\
24.3 \\
\pm 0.9\end{array}$ & $\begin{array}{l}18.5 \\
18.7 \\
19.0 \\
17.2 \\
17.0 \\
19.7 \\
16.5 \\
18.8 \\
16.8 \\
19.7 \\
18.2 \\
\pm 1.2\end{array}$ \\
\hline
\end{tabular}

dry condition at $10^{\circ} \mathrm{C}$. Macroconidia from lactophenol, and the dimensions of 25 spores per root were measured as described above.

Confirmation of the identity of FSB. FSB isolates F-465 and FSB-2 were compared with $F$. solani ATCC reference cultures no. 46472 and no. 11712. In contrast to fresh isolates of FSB, which sporulate well on PDA $(34,35)$, the $F$. solani ATCC isolates did not sporulate well on this medium when first received. After selected sporulating sectors from PDA were cultured on modified Bilay's medium in light, the ATCC isolates sporulated profusely. On that basis, modified Bilay's medium was selected for comparison of reproductive structures. Isolates were grown on this medium at $25^{\circ} \mathrm{C}$ under continuous fluorescent light $\left(38 \mu \mathrm{E} \mathrm{s}^{-1} \mathrm{~m}^{-2}\right)$. After 7 days, dimensions of macroconidia (100 per isolate) were determined as described above, and observations on conidial characteristics were made. Isolates were grown on PDA for observations on colony morphology. For chlamydospore production and characteristics, cultures were aged up to 3 weeks and plugs of mycelium were incubated in sterile water.

Comparative cultural and morphological characteristics of FSB and $P$. cucumerina. Characterization of $P$. сисиmerina was limited primarily to the conidial stage of this fungus.

Based on reports that the optimal temperatures for growth of $P$. cucumerina (56) and FSB (39) on PDA were 25 and $30^{\circ} \mathrm{C}$, respectively, and that $P$. cucumerina did not grow at $35^{\circ} \mathrm{C}(56)$, growth rates and responses of $P$. cucumerina and FSB to temperature were compared at 25,30 , and $35^{\circ} \mathrm{C}$. P. cucumerina isolates IN-2X-11, IN-11P-12, and IN-11-12 and FSB isolates F-465, FSB-6, and FSB-2 were grown on PDA in darkness for 7 days at the three temperatures, after which colony diameters were determined as described above. Each treatment was replicated seven times, the

Table 3. Colony diameters $(\mathrm{mm})$ of 10 isolates tex srowth on three different temperatures each root were mounted in cotton blue- ments were compared by analysis of variance. Colony characteristics and production of chlamydospores at $25^{\circ} \mathrm{C}$ also were determined in this experiment. Isolates were grown for 7 days on PDA at $25^{\circ} \mathrm{C}$ with continuous exposure to fluorescent light $\left(38 \mu \mathrm{E} \cdot \mathrm{s}^{-1} \cdot \mathrm{m}^{-2}\right)$ for observations on colony and conidial characteristics and production of chlamydospores. In addition, colonies were aged up to 3 weeks, and plugs of mycelium were placed in sterile water for observations on chlamydospore production. Dimensions of conidia (100 per isolate) were determined as described above.

\section{RESULTS}

Comparative pathogenicity tests with FSA and $F$. solani f. sp. phaseoli. Although mild chlorosis occurred on a few plants, no leaf symptoms typical of SDS occurred on any plants inoculated with isolates of $F$. solani $\mathrm{f}$. sp. phaseoli in the field in test 1 or in pots in test 2. Leaf symptoms typical of SDS occurred on $24 \%$ of the plants inoculated with FSA in test 1 and on $43 \%$ of those inoculated in test 2 . In test 1 , symptoms did not progress beyond mild interveinal necrosis on those leaves first symptomatic. In test 2 , there also was little interveinal necrosis, but newly symptomatic leaves appeared on plants as late as the R5 growth stage. In the growth chamber tests 3 and 4 (Table 2), isolates of F. solani f. sp. phaseoli did not incite SDS leaf symptoms, but the incidence of FSAinoculated plants showing SDS leaf symptoms was greater than in tests 1 and 2 . Slight root necrosis was incited by $F$. solani f. sp. phaseoli no. 38466, and moderate root necrosis was incited by FSA (Table 2). The fungi were reisolated from surface-disinfested, symptomatic roots.

Cultural and morphological characteristics of FSA. FSA isolates grew slowly on PDA (Table 3). After 7 days at $25^{\circ} \mathrm{C}$, colony diameters ranged from ca. 23 to 36 $\mathrm{mm}$ and averaged $24 \mathrm{~mm}$. Growth at $25^{\circ} \mathrm{C}$ was greater than at 20 and $30^{\circ} \mathrm{C}$. At each temperature, variability in mean growth rate among isolates was relatively low, based on standard deviations $( \pm 0.9,0.9$, and 1.2 at 20,25 , and $30^{\circ} \mathrm{C}$, respectively).

Colony morphology and pigmentation were the same on PDASA and PDA. Colonies of FSA growing from root sections and those initiated from single spores or mass transfer exhibited similar characteristics. The blue pigmentation that has become associated with the SDS causal agent $(34-36,40,41)$ was invariably produced by fresh cultures of FSA. However, colonies exhibited considerable variation in surface pigmentation due largely to the amount of sporulation. Within 2 to 3 days after infected root tissue was cultured on PDASA, sporodochia formed in situ and on the agar surface. Sporodochia of these wild-type colonies soon became confluent, producing effuse pionnote sporodochia (pseudopion- 
notes) with slimy masses of blue to bluegreen macroconidia (Fig. 1A and B). When viewed in situ microscopically $(100 \times)$, the conidia appeared reddish blue to dark blue. Isolates with varying degrees of sporula- tion produced colonies with varying amounts of blue pigmentation. In some profusely sporulating isolates, the blue to blue-green conidial masses occupied nearly the entire colony surface except for an

Table 4. Dimensions of macroconidia of Fusarium solani form A isolates after growth of colonies on modified Bilay's medium for 7 days at $25^{\circ} \mathrm{C}$ under continuous fluorescent light $\left(38 \mu \mathrm{E} \cdot \mathrm{s}^{-1} \cdot \mathrm{m}^{-2}\right)$

\begin{tabular}{lccccc}
\hline & \multicolumn{4}{c}{ Size of macroconidia $^{\mathbf{z}}$} \\
\cline { 2 - 3 } \cline { 5 - 6 } Isolate & \multicolumn{2}{c}{ Mength $(\boldsymbol{\mu m})$} & \multicolumn{2}{c}{ Width $(\boldsymbol{\mu m})$} \\
\cline { 2 - 3 } \cline { 5 - 6 } IN-F2X-11A & 46.5 & $38.0-55.0$ & & 4.5 & Mean \\
91-7 & 46.1 & $40.0-55.0$ & & 4.4 & $4.0-5.0$ \\
A-15 & 53.2 & $43.8-61.3$ & & 4.8 & $3.0-5.0$ \\
A-16 & 49.2 & $41.8-59.4$ & & 4.7 & $3.9-4.9$ \\
A-11 & 52.6 & $40.8-66.1$ & & 4.6 & $3.9-4.9$ \\
A-12 & 49.7 & $34.1-58.4$ & & 4.5 & $3.9-4.9$ \\
A-13 & 53.3 & $40.9-59.4$ & & 4.5 & $3.9-4.9$ \\
A-14 & 53.3 & $40.9-63.2$ & & 4.4 & $3.9-4.9$ \\
A-17 & 51.1 & $42.8-63.2$ & & 4.8 & $3.9-4.9$ \\
$94-1$ & 50.0 & $40.0-60.0$ & & 4.5 & $4.0-5.0$ \\
Mean across isolates & 50.5 & & & 4.6 & \\
Standard deviation & \pm 2.7 & \pm 0.2 & & \\
\hline
\end{tabular}

${ }^{\mathrm{z}}$ Fifty conidia measured per isolate.

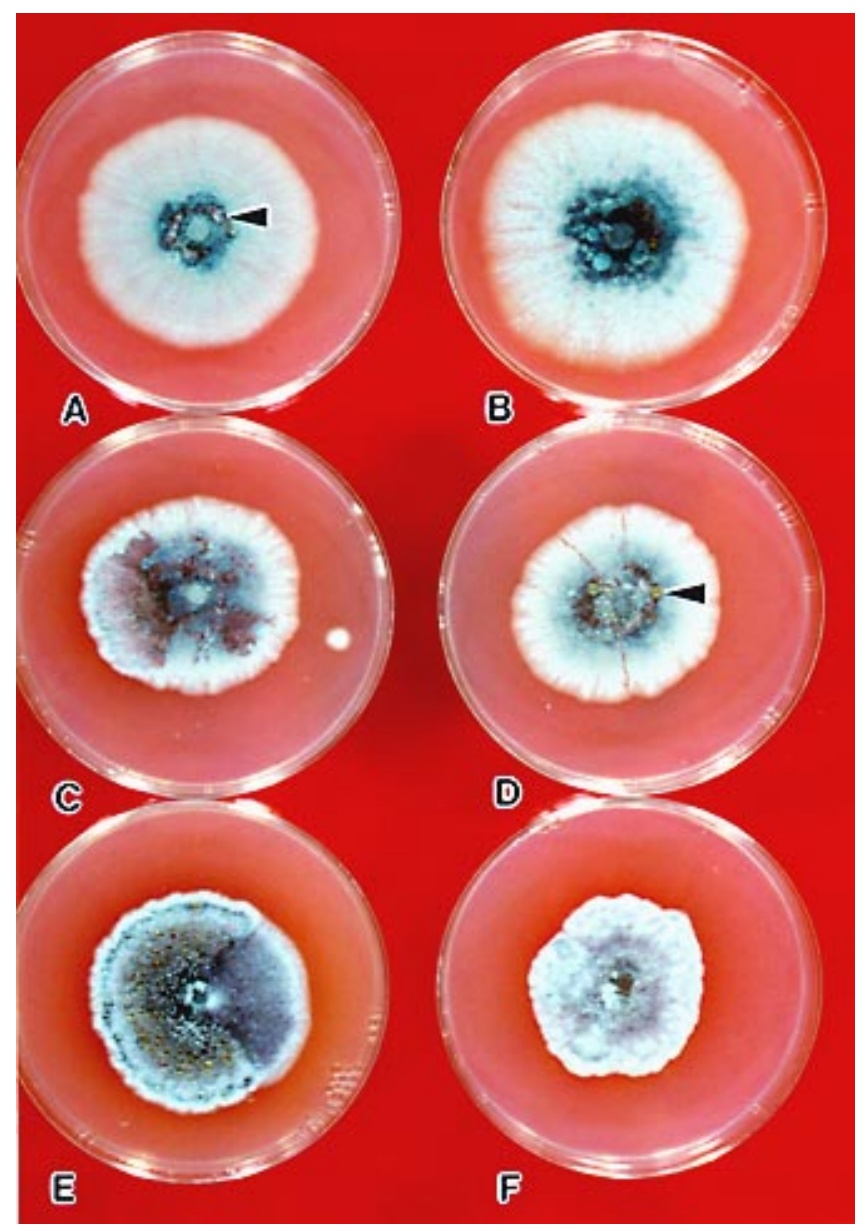

Fig. 1. Variability in the surface morphology and pigmentation of approximately 14-day-old colonies of Fusarium solani form A isolates on potato-dextrose agar (PDA). Isolates (A) A-15, (B) A-11, (C) A-14, (D) A-16, and (E) A-13 are first- or second-generation subcultures recovered from roots. Note typical blue to blue-green dominant pigmentation (A and B) with admixture of usually later produced dark blue (A and B), purple (C and D), and violet (E) pigmentation, and cream-colored spore masses (arrows; A and D). Isolate (F) A-15 was subcultured on PDA several times and stored in a PDA slant for 8 months prior to being transferred to plates of PDA.

outer fringe of grayish white, nonsporulating hyphae. The conidial mass radiating outward from the colony center usually was continuous, but small scattered groups of sporodochia sometimes appeared (Fig. 1B). Scattered, small, cream-colored conidial masses sometimes occurred in the older, central part of the colony (Fig. 1A and D). Dark blue (Fig. 1A and B), purple (Fig. 1C and D), and violet (Fig. 1E) spore masses tended to form and become admixed to varying degrees with the blue to blue-green spore masses as colonies aged. The purple or violet spore masses also occurred in wild-type colonies, but much less frequently than blue to blue-green spore masses, and they sometimes occurred as sectors radiating from the center (Fig. $1 \mathrm{C}$ and $\mathrm{E})$, particularly in isolates subcultured on PDA for several generations. Transfers from purple or violet spore masses usually produced, at least initially, colonies with blue to blue-green spore masses. Prolonged storage of FSA on PDA slants invariably reduced sporulation and typical surface pigmentation with a concomitant increase in nonsporulating aerial mycelium (Fig. 1F). Transfers from sporulating regions of colonies that had become almost entirely mycelial usually gave rise to sporulating cultures.

On modified Bilay's medium, macroconidia ranged in size from ca. 34 to $66 \mu \mathrm{m}$ long by 3.9 to $5.0 \mu \mathrm{m}$ wide, and across isolates, they averaged $50.5 \mu \mathrm{m}$ long by 4.6 $\mu \mathrm{m}$ wide (Table 4). Variability in mean length and width of macroconidia among the isolates was relatively low, based on standard deviations $( \pm 2.7$ for length and \pm 0.2 for width). Dimensions of macroconidia produced on soybean roots in the field ranged from 38 to $48 \mu \mathrm{m}$ long by 3.8 to 5.0 $\mu \mathrm{m}$ wide and averaged $42.5 \mu \mathrm{m}$ long by 4.5 $\mu \mathrm{m}$ wide.

Confirmation of the identity of FSB. Colonies of FSB and the ATCC isolates of F. solani on PDA were very similar in appearance and, from a practical standpoint, were indistinguishable (Fig. 2). Although colony diameters were not measured, growth rates of the FSB and $F$. solani ATCC isolates were similar, as exemplified in Figure 2. On modified Bilay's medium, there were no fundamental differences among these isolates with respect to conidiogenesis, the morphology of conidiophores, microconidia, and macroconidia, and the morphology and arrangement of chlamydospores within hyphae $(4,7,27)$. There was some variation among isolates in average size of macroconidia, but range in size was comparable (Table 5).

Comparative cultural and morphological characteristics of FSB and $P$. cucumerina. Colony diameters of each of the FSB isolates were significantly different $(P \leq 0.05)$ from those of the $P$. cucumerina isolates at 25,30 , and $35^{\circ} \mathrm{C}$. At $25^{\circ} \mathrm{C}$, the average colony diameter (across three isolates) of P. cucumerina was $50 \%$ 
of the average colony diameter (across three isolates) of FSB $(56 \mathrm{~mm})$. At $30^{\circ} \mathrm{C}$, the average colony diameter of $P$. сисиmerina was $43 \%$ of the average for FSB $(71 \mathrm{~mm})$. At $35^{\circ} \mathrm{C}$, a temperature at which FSB grew well $(48 \mathrm{~mm}), P$. cucumerina did not grow. The disparity in growth rate is exemplified in Figure 3.

On PDA at $25^{\circ} \mathrm{C}, 7$-day-old colonies of FSB produced a cream-colored to tan mycelium (Fig. 3). Sporodochia were usually cream-colored to buff, mainly scattered, or less often, in a concentric pattern. With aging, relatively small bluish or greenish sporodochia were produced by some isolates. Three- and four-septate macroconidia predominated in FSB isolates, but macroconidia with more than four septa also were produced. The long microconidiophores with false heads of typically aseptate, but sometimes one-septate, microconidia were perhaps routinely the most easily recognizable and useful character in preliminary identification of FSB. It was common for fresh isolates to produce microconidiophores that exceeded $200 \mu \mathrm{m}$ in length. Microconidia ranged in size from 11 to $15 \mu \mathrm{m}$ long by 2 to $4 \mu \mathrm{m}$ wide. Chlamydospores were produced singly or in pairs in the hyphae and measured 6.9 to $9.4 \mu \mathrm{m}$ diameter. No sexual fruiting bodies were formed by FSB. Seven-day-old colonies of $P$. cucumerina produced a creamcolored to pinkish mycelium (Fig. 3). Conidiophores of $P$. cucumerina did not aggregate into sporodochia, but were often produced on hyphal ropes in the older part of the colony. Aging colonies grown in darkness were observed to produce radial folds, but this was not observed for colonies in continuous light. The majority of the conidia in $P$. cucumerina were aseptate, some were one-septate, and a few were two-septate. Some of these fell within the size range of FSB microconidia, but they were substantially smaller than FSB macroconidia (Table 6). P. cucumerina did not produce chlamydospores. After 8 to 10 days of growth, the fungus began producing perithecia. After an additional 3 to 7 days, brown perithecia typical for this species $(4,7)$ occupied much of the colony of each isolate.

\section{DISCUSSION}

Isolates of $F$. solani $\mathrm{f}$. sp. phaseoli did not incite the leaf symptoms characteristic of SDS $(23,34,36,37,40)$, while isolates of FSA did. In other laboratories, isolates of $F$. solani f. sp. phaseoli (3) and isolates of F. solani from bean $(16,17)$ also did not incite SDS leaf symptoms when inoculated on soybean. Therefore, $F$. solani f. sp. phaseoli and FSA are not the same forma specialis, and $F$. solani $\mathrm{f}$. sp. phaseoli is not the causal agent of SDS. The present study reaffirms that FSA is the causal agent of SDS, and this is supported by other past and present sources of evidence. Considering that the FSA type of Roy et al. (34) and the blue-pigmented $F$. solani strain of Rupe (40) are the same fungus (41; J. C. Rupe, personal communication), Koch's postulates were completed for SDS with isolates of this fungus at least four times $(23,34,40,52)$. In contrast, Koch's postulates have never been completed for SDS with bona fide cultures of $F$. solani $\mathrm{f}$. sp. phaseoli. Although O'Donnell and Gray (28) inoculated soybean with an isolate of F. solani ("Mont-1"), reproduced the symptoms of SDS, and reisolated the fun- gus from diseased tissue, "Mont-1" and isolates of FSA they used in their study were identical based on molecular analyses. Thus, in essence, they completed Koch's postulates with an additional isolate of FSA rather than with $F$. solani $\mathrm{f}$. sp. phaseoli, and thereby confirmed the earlier etiological findings $(23,34,40,52)$. In addition, although O'Donnell and Gray emphasized the close genetic relatedness of FSA and $F$. solani $\mathrm{f}$. sp. phaseoli, the unique nucleotide base pair substitution they

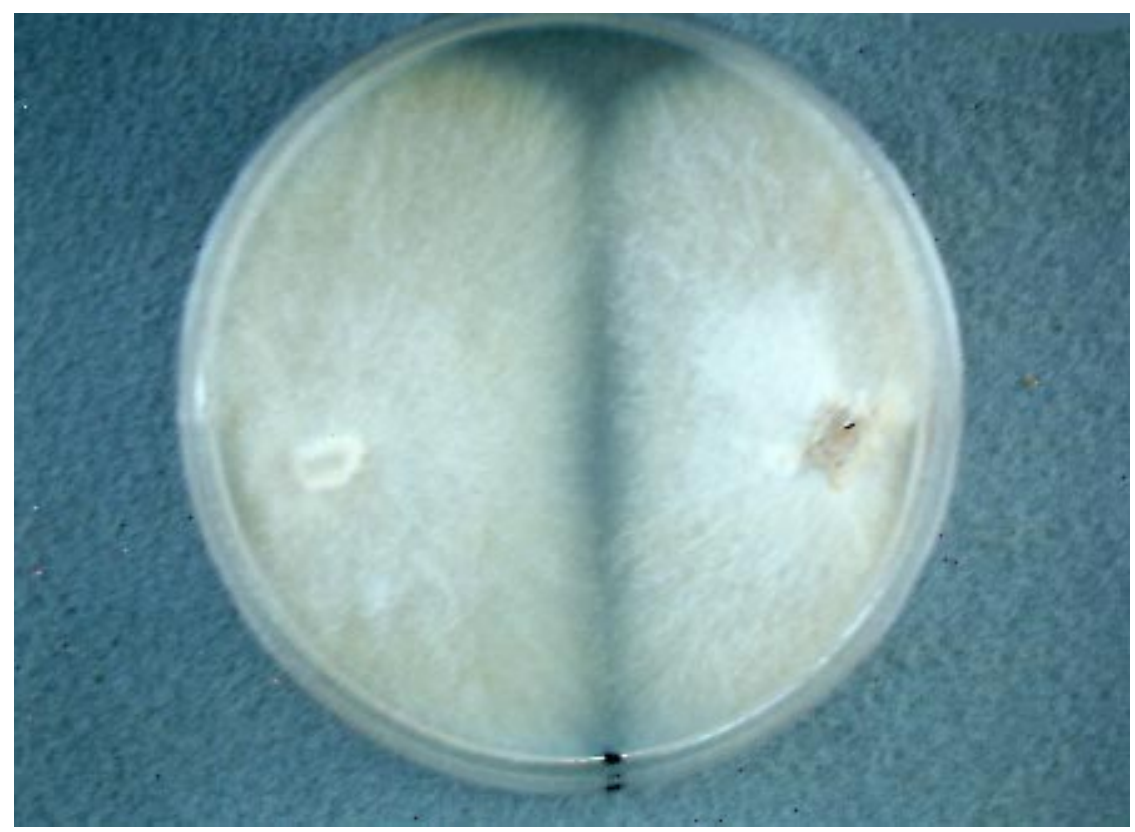

Fig. 2. Comparison of Fusarium solani form B isolate F-465 (left) and F. solani American Type Culture Collection isolate no. 46472 (right) colonies and growth rates on potato-dextrose agar.

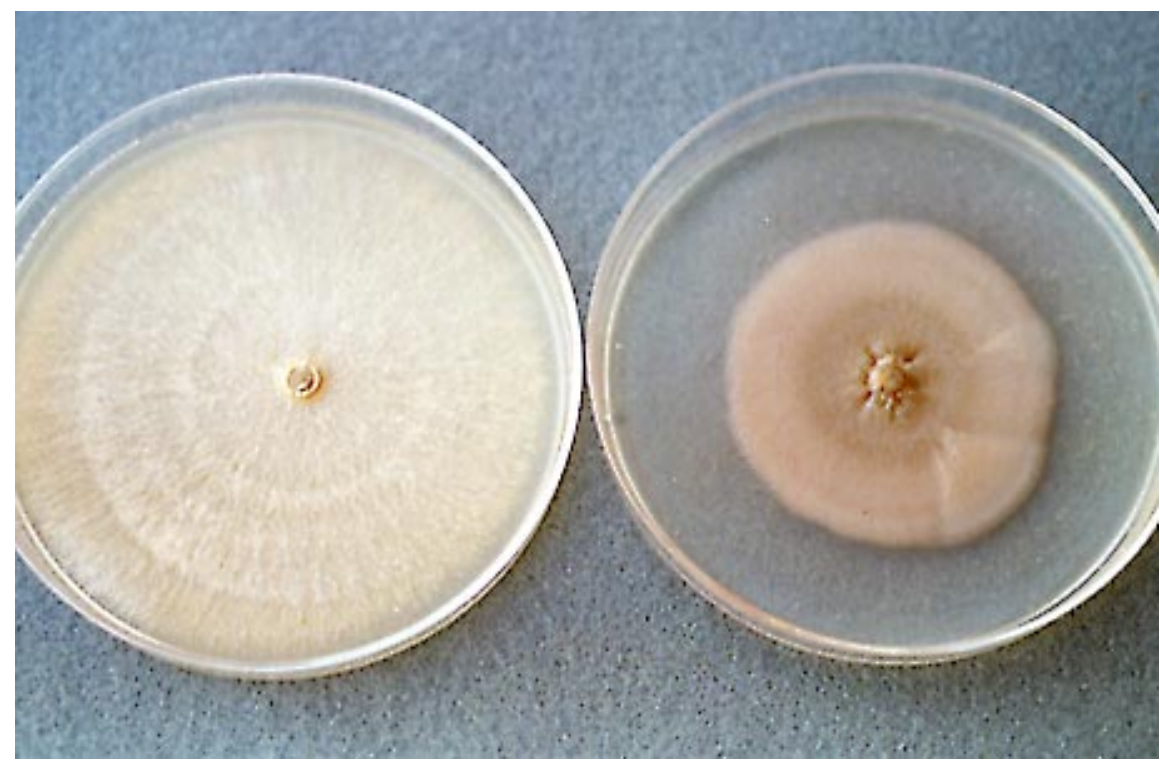

Fig. 3. Comparison of Fusarium solani form B isolate F-465 (left) and Plectosphaerella cucumerina isolate IN-2X-11N (right) colonies and growth rates on potato-dextrose agar 
found for FSA may reflect a difference from $F$. solani f. sp. phaseoli consistent with pathogenicity results of the present study and with studies by Achenbach et al. (3) and Rupe et al. (42). Although still maintaining that SDS-inciting isolates of $F$. solani represented a subgroup within $F$. solani f. sp. phaseoli, Achenbach et al. (3) found such isolates to be distinct from this forma specialis on the basis of random amplified polymorphic DNA (RAPD) analysis. Rupe et al. found from mitochondrial DNA restriction fragment length polymorphism analyses that SDS-inciting isolates of $F$. solani from soybean were genetically distinct from nonsoybean isolates of $F$. solani that did not incite SDS (42), some of which were $F$. solani f. sp. phaseoli (J. C. Rupe, personal communication).

Host adaptation and the nature of the symptoms a causal agent incites on hosts are essential features of formae speciales $(4,15)$. In the 55 years since the $F$. solani bean root rot pathogen was designated a forma specialis adapted to Phaseolus (48), only one report (28) associated this fungus with a disease of soybean. Indeed, soybean has been considered a nonhost of $F$. solani f. sp. phaseoli and thus potentially useful as a rotation crop in controlling bean root rot and in reducing $F$. solani f. sp. phaseoli soil inoculum $(21,45,49)$. Particularly illuminating in this regard are results of a rotation study conducted in a field with a history of bean root rot: the inoculum density of $F$. solani f. sp. phaseoli alternately decreased when soybeans were grown and increased when beans were grown (13), and furthermore, SDS leaf symptoms were not observed to occur on soybean plants (R. Hall, personal communication). Melgar and Roy (22) inoculated 21 plant species with FSA and found that the fungus could infect only nonwounded soybean and mung bean (Vigna radiata (L.) R. Wilcz.) and wounded green bean, cowpea (V. unguiculata (L.) Walp. subsp. unguiculata), and lima bean (Phaseolus lunatus L.) plants. Gray (11) also reported that soybean, mung bean, and green bean were hosts of the SDS causal agent. Thus, although FSA and F. solani f. sp. phaseoli both can infect soybean (Table 2; 22), mung bean $(22,46)$, green bean, cowpea, and lima bean roots $(8,14,22)$, their requirements for pathogenicity are different; wounding of green bean, cowpea, and lima bean roots was required for infection by $\mathrm{FSA}$, indicating that these plant species were less compatible as hosts than soybean and mung bean (22); whereas wounding was not required for infection of these plant species by $F$. solani f. sp. phaseoli $(45,49,53)$. More important, however, is the distinction that has been made between FSA and $F$. solani f. sp. phaseoli based on the types of symptoms they incite on soybean: F. solani f. sp. phaseoli incites mild necrosis on soybean roots but does not incite SDS leaf symptoms, while FSA incites greater root necrosis and also typical SDS leaf symptoms (Table 2; 34-36).

Messiaen and Cassini (24) considered $F$. solani to be less specialized in its host adaptation than other fusaria, e.g., $F$. oxysporum, and therefore formae speciales of $F$. solani are determined more by the types

Table 5. Comparative dimensions of macroconidia of Fusarium solani form B isolates and isolates of F. solani from the American Type Culture Collection after growth of colonies on modified Bilay's medium for 7 days at $25^{\circ} \mathrm{C}$ under continuous fluorescent light $\left(38 \mu \mathrm{E} \cdot \mathrm{s}^{-1} \cdot \mathrm{m}^{-2}\right)$

\begin{tabular}{|c|c|c|c|c|c|}
\hline \multirow[b]{3}{*}{ Fungus } & \multirow[b]{3}{*}{ Isolate no. } & \multicolumn{4}{|c|}{ Size of conidia ${ }^{y}$} \\
\hline & & \multicolumn{2}{|c|}{ Length $(\mu \mathrm{m})$} & \multicolumn{2}{|c|}{ Width $(\mu \mathrm{m})$} \\
\hline & & Mean & Range & Mean & Range \\
\hline F. solani form B & F-465 & 33.8 & $24-46$ & 4.4 & $4-5$ \\
\hline F. solani form B & FSB-2 & 34.6 & $29-43$ & 4.4 & $4-5$ \\
\hline F. solani & $46472^{z}$ & 36.1 & $29-46$ & 4.7 & $4-6$ \\
\hline F. solani & $11712^{z}$ & 31.6 & 24-39 & 4.3 & $4-5$ \\
\hline
\end{tabular}

y One hundred conidia measured per isolate.

${ }^{\mathrm{z}}$ American Type Culture Collection isolate numbers.

Table 6. Comparative dimensions of Fusarium solani form B macroconidia and Plectosphaerella cucumerina conidia after growth of colonies on potato-dextrose agar for 7 days at $25^{\circ} \mathrm{C}$ under continuous fluorescent light $\left(38 \mu \mathrm{E} \cdot \mathrm{s}^{-1} \cdot \mathrm{m}^{-2}\right)$

\begin{tabular}{|c|c|c|c|c|c|}
\hline \multirow[b]{3}{*}{ Fungus } & \multirow[b]{3}{*}{ Isolate no. } & \multicolumn{4}{|c|}{ Size of conidia ${ }^{z}$} \\
\hline & & \multicolumn{2}{|c|}{ Length $(\boldsymbol{\mu m})$} & \multicolumn{2}{|c|}{ Width $(\mu \mathrm{m})$} \\
\hline & & Mean & Range & Mean & Range \\
\hline F. solani form B & F-465 & 37.8 & $27-51$ & 4.8 & $4-6$ \\
\hline F. solani form B & FSB-6 & 34.5 & $26-50$ & 4.7 & $4-6$ \\
\hline F. solani form B & FSB-2 & 38.6 & $32-48$ & 4.7 & $4-6$ \\
\hline P. cucumerina & IN-11-12 & 8.0 & $7-9$ & 2.7 & $2-3$ \\
\hline P. cucumerina & IN-11P-12 & 7.4 & $6-11$ & 2.4 & $2-3$ \\
\hline P. cucumerina & IN-2X-11 & 6.7 & $6-8$ & 2.4 & $2-3$ \\
\hline
\end{tabular}

${ }^{\mathrm{z}}$ One hundred conidia measured per isolate. of symptoms they incite than by host specialization per se. For example, F. solani f. sp. phaseoli, the bean root rot pathogen, and F. solani f. sp. pisi (F.R. Jones) W.C. Snyder \& H.N. Hans., the pea root rot pathogen, each cause mild necrosis on roots of the opposite host but a serious disease only on the designated host (30). Also, $F$. solani f. sp. eumartii (C. Carpenter) W.C. Snyder \& H.N. Hans. and race 2 of $F$. solani f. sp. radicicola (Wr.) W.C. Snyder \& H.N. Hans. both infect potato but incite different symptoms $(4,24)$. Thus, a parallel situation appears to exist for FSA and $F$. solani f. sp. phaseoli.

The ability of $F$. solani $\mathrm{f}$. sp. phaseoli to incite limited necrosis on soybean roots is not unusual, since FSB $(18,19,34)$, the $F$. solani associated with Essex syndrome (12), and other F. solani strains from soybean $(3,10,55)$ can also cause necrosis on soybean roots. None of these fungi, however, incite SDS leaf symptoms. An ability to incite necrosis on soybean roots is not decisive in assigning causality for SDS because leaf symptoms can be incited independently of root symptoms, as shown by Roy et al. (34). They wound-inoculated FSA into soybean hypocotyls, and with no involvement of root necrosis, leaf symptoms typical for SDS were produced. Such results suggest the involvement of a phytotoxin in leaf symptom expression, and this is substantiated by more direct evidence. Jin et al. (16) identified a polypeptide from culture filtrates of SDS-inciting isolates of $F$. solani from soybean that caused some of the leaf symptoms of SDS. Isolates of $F$. solani that did not incite SDS leaf symptoms on soybean also failed to produce the phytotoxic polypeptide; most of the nonsoybean isolates were from leguminous plant species, including two from bean $(16,17)$. In contrast, phytotoxins are not involved in the etiology of bean root rot, caused by $F$. solani f. sp. phaseoli $(5,20)$. The results of Jin et al. $(16,17)$ are compatible with those in the present study and strongly suggest that the unique ability of FSA to incite SDS leaf symptoms is conferred, at least in part, by the phytotoxic polypeptide.

In addition to the above distinctions between FSA and F. solani f. sp. phaseoli, the host range of FSA (22) differs from the host ranges of other formae speciales of $F$. solani $(4,20,48)$. Thus, cumulative evidence indicates that the unique ability of FSA to incite SDS, particularly the leaf symptoms, and its relatively limited host range, warrant its designation as a forma specialis (15). Therefore, FSA is designated $F$. solani (Mart.) Sacc. f. sp. glycines form. nov. Representative cultures of the fungus from soybean roots and SCN cysts have been deposited with the ATCC. Isolates representative of $F$. solani f. sp. glycines are described in this and other studies (34-36). In addition to their capacity to incite SDS symptoms in soybean, $F$. solani 
f. sp. glycines isolates are further distinguished from other forms of $F$. solani that occur on soybean roots $(12,34,38)$ by several morphological features. $F$. solani $\mathrm{f}$. sp. glycines grows more slowly (Table 3 ) and has longer macroconidia (Table 4) than FSB (34-36), the Essex syndrome $F$. solani (12), and F. solani f. sp. pisi $(20,54)$. Moreover, F. solani f. sp. glycines rarely, if ever, produces microconidia, in contrast to FSB (34-36), the Essex syndrome $F$. solani (12), and F. solani f. sp. pisi $(20,30)$.

Evidence from this study clearly shows that FSB and P. cucumerina are not conspecific. Apparently, authentic cultures representative of FSB (Figs. 2 and 3; $18,19,34,35)$ were not used in an earlier study that concluded FSB and P. сисиmerina were conspecific (28). Colonies of FSB are easily distinguishable from those of $P$. cucumerina, and FSB grows faster and at temperatures beyond what $P$. сисиmerina will tolerate. Other characteristics of FSB that distinguish it from $\mathrm{P}$. $\mathrm{Cucu}$ merina are the production of sporodochia, lack of hyphal ropes, production of both macroconidia and microconidia, production of conidia that are larger and have more septa, production of chlamydospores, and absence of a sexual stage.

There are other distinctions, ecological and pathological in nature, between the two fungi. F. solani, including FSB, is one of the most common fungi isolated from surface-disinfested SCN cysts $(6,26,32$, 38,39). Although $P$. cucumerina has been isolated from cysts (6), it is not a common isolate. Carris et al. (6) isolated P. cucumerina from three, and $F$. solani from about 800 of 5,000 assayed cysts. P. cucumerina causes no known disease on soybean, its pathogenicity to plants is seldom demonstrated, and it is a relatively weak pathogen on its plant hosts $(4,7,29,56)$. Pathogenicity of FSB on soybean is well documented $(18,19,34)$.

Results of the comparison of FSB with ATCC isolates of $F$. solani confirm that FSB is $F$. solani. The ATCC isolates were virtually indistinguishable from FSB, and they are representative of FSB isolates originating from soybean root tissue or SCN cysts $(19,32,34,39)$. Cultures of FSB from soybean roots and SCN cysts, and cultures of $P$. cucumerina from soybean roots, have been deposited with the ATCC.

It is possible that a Cephalosporiopsis sp. isolated from soybean reproductive structures (25), which has some similarities with the conidial stage of $P$. cucumerina $(4,7)$, is actually the latter species. Pascoe et al. (29) initially identified $P$. cucumerina as Cephalosporiopsis, and C. imperfecta $\mathrm{F}$. $\& \mathrm{~V}$. Moreau is a synonym of the anamorph (7).

FSB is one of several strains of $F$. solani that occur on soybean roots $(10,12,18,19$, 34,55). This situation is typical for soilborne fusaria, and it parallels the situation in bean, where saprophytic and plant- pathogenic clones of $F$. solani coexist (47). FSB is not defined as a narrowly circumscribed morphological entity $(34,35)$. This fungus was never formally described in a taxonomic sense, and the word "form" implies no taxonomic significance. To have defined it as such would have disregarded the other strains of $F$. solani on soybean that also are not well delineated morphologically $(10,12,55)$. Rather, FSB represents a strain that is morphologically and pathogenically distinct from $F$. solani $\mathrm{f}$. sp. glycines and is comprised of pathogenic $F$. solani isolates that cause seedling disease and root rot of older soybean plants $(18,19,34)$. FSB should not be equated with strains of $F$. solani that occur on aerial parts of soybean because no comparison has been made of their morphological characteristics and pathogenic capabilities. Strains from aerial parts of soybean may differ from FSB, based on previous observations (25).

It is clear from careful reading of the literature and from the results presented in this study that $F$. solani $\mathrm{f}$. sp. glycines and FSB are morphologically distinct fungi that incite separate and distinct soybean diseases. Further, more subtle distinctions were recently reported. In contrast to $F$. solani f. sp. glycines, FSB occurs in soybean roots and SCN cysts regardless of the presence of SDS (39), and it does not produce conspicuous blue masses of macroconidia on diseased roots in the field $(24,38)$. Because the complex of $F$. solani strains on soybean roots includes, in addition to F. solani f. sp. glycines and FSB, the $F$. solani involved in the etiology of Essex syndrome (12), F. solani f. sp. pisi (38), and possibly other strains $(10,12,55)$, much work remains in characterizing the entire complex and distinguishing members of the complex from each other and particularly from $F$. solani f. sp. glycines and FSB. Meanwhile, it is not sufficient to refer to isolates of $F$. solani from soybean roots merely as $F$. solani without at least briefly describing their salient morphological features. Failure to do so likely will lead to their confusion with $F$. solani f. sp. glycines or FSB, or to other complications. The cultural history, pathogenic history, and source of an $F$. solani isolate from soybean cannot be disregarded. For example, Achenbach et al. (3) provided little such information with respect to isolates of FSA, particularly FSA-1. They incorrectly cited Melgar et al. (23) as "Melgar and Roy" to document cultural conditions under which FSA-1 was maintained and the method by which it had previously been tested for pathogenicity, while omitting the correct article (22). FSA-1 was not used by Melgar et al. (23); the FSA isolate they used was inoculated by infestation of soil in field microplots, and SDS leaf symptoms were incited. Furthermore, Achenbach et al. (3) listed K. Roy as the source of FSA-1 for their study, which implies that Roy maintained FSA-1 in culture immediately prior to its use in their study. In fact, Roy recovered FSA-1 in 1989 from soybean plants exhibiting SDS foliar symptoms, gave a culture of this isolate to another researcher (not a coauthor of Achenbach et al.) in 1990, and thereafter had no knowledge of its history. Conclusions by Achenbach et al. (3) that the isolates of FSA they tested no longer "produce" SDS foliar symptoms and that this might be explainable on the basis of repeated subculturing of isolates or dissimilar methods of inoculations in their study compared with the study by "Melgar and Roy" must be evaluated in light of the aforementioned facts.

Confusion regarding the identity and characteristics of pathogenic forms of $F$. solani from soybean confounds the literature and impedes progress in understanding and managing the soybean diseases caused by $F$. solani. This is particularly important with respect to SDS, a disease already complicated enough by the interactive involvements of soybean, $F$. solani f. sp. glycines, and $\operatorname{SCN}(23,32,34,36,39,40,44)$.

\section{ADDENDUM}

Four papers published in 1996 or 1997 in the journal Crop Science referred to the SDS causal agent as $F$. solani type A (Njiti et al., 36:1165-1170) or $F$. solani f. sp. phaseoli type A (Chang et al., 36:16841688; Hnetkovsky et al., 36:393-400; and Njiti et al., 37:132-138). The ill-chosen and certain-to-be-confusing abbreviation "FSA" was used by Hnetkovsky et al. for F. solani f. sp. phaseoli type A. An article published in 1996 by Gray and Achenbach in the journal Plant Disease (80:11971199 ) ironically referred to the SDS causal agent as represented by "specific isolates" of $F$. solani rather than $F$. solani f. sp. phaseoli, as proposed by Gray only a year earlier in O'Donnell and Gray (28). Moreover, Gray and Achenbach cited J. Rupe as the source of isolate FSA-1, and in contrast to the report by Achenbach et al. (3), which was also published in 1996, this isolate incited SDS leaf symptoms on all soybean plants inoculated by Gray and Achenbach in each of four trials. It was noted that neither the Crop Science papers nor the Gray and Achenbach paper cited the work of O'Donnell and Gray which originally applied the name $F$. solani f. sp. phaseoli to the SDS causal agent (28).

\section{ACKNOWLEDGMENTS}

I thank Sunil Ratnayake and Bert Riggans for technical assistance. Supported in part by funds provided by the American Soybean Association and the Mississippi Soybean Promotion Board.

\section{LITERATURE CITED}

1. Abney, T. S., Richards, T. L., Ivanovich, A. J., and Scott, D. H. 1989. Highly virulent isolates of Fusarium solani from soybeans produce the Nectria ascoma stage. (Abstr.) Phytopathology 79:1136-1137. 
2. Abney, T. S., Richards, T. L., and Roy, K. W. 1993. Fusarium solani from ascospores of Nectria haematococca causes sudden death syndrome of soybean. Mycologia 85:801-806

3. Achenbach, L. A., Patrick, J., and Gray, L. 1996. Use of RAPD markers as a diagnostic tool for the identification of Fusarium solani isolates that cause soybean sudden death syndrome. Plant Dis. 80:1228-1232.

4. Booth, C. 1971. The Genus Fusarium. Commonw. Mycol. Inst., Kew, Surrey, England.

5. Burke, D. W., and Hall, R. 1991. Fusarium root rot. Pages 9-10 in: Compendium of Bean Diseases. R. Hall, ed. American Phytopathological Society, St. Paul, MN

6. Carris, L. M., Glawe, D. A., Smyth, C. A., and Edwards, D. I. 1989. Fungi associated with populations of Heterodera glycines in two Illinois soybean fields. Mycologia 81:6675.

7. Domsch, K. H., Gams, W., and Anderson, T. H. 1980. Compendium of Soil Fungi. Vol. I. Academic Press, London.

8. Farr, D. F., Bills, G. F., Chamuris, G. P., and Rossman, A. Y. 1989. Fungi on Plants and Plant Products in the United States. American Phytopathological Society, St. Paul, MN.

9. Fehr, W. R., Caviness, C. E., Burmond, D. L., and Pennington, J. S. 1971. Stages of development descriptions for soybeans, Glycine $\max ($ L.) Merrill. Crop Sci. 11:929-931.

10. Ferrant, N. P., and Carroll, R. B. 1981. Fusarium wilt of soybean in Delaware. Plant Dis. 65:596-599.

11. Gray, L. E. 1991. Alternate hosts of soybean SDS strains of Fusarium solani. (Abstr.) Phytopathology 81:1135

12. Griffin, G. L. 1990. Importance of Pythium ultimum in a disease syndrome of cv. Essex soybean. Can. J. Plant Pathol. 12:135-140.

13. Hall, R., and Phillips, L. G. 1992. Effects of crop sequence and rainfall on population dynamics of Fusarium solani f. sp. phaseoli in soil. Can. J. Bot. 70:2005-2008.

14. Harter, L. L., and Zaumeyer, W. J. 1944. A monographic study of bean diseases and methods of their control. U.S. Dep. Agric. Tech. Bull. 868 .

15. Hawksworth, D. L. 1974. Mycologist's Handbook. Commonw. Mycol. Inst., Kew, Surrey, England.

16. Jin, H., Hartman, G. L., Nickell, C. D., and Widholm, J. M. 1996. Characterization and purification of a phytotoxin produced by Fusarium solani, the causal agent of soybean sudden death syndrome. Phytopathology 86:277-282.

17. Jin, H., Hartman, G. L., Nickell, C. D., and Widholm, J. M. 1996. Phytotoxicity of culture filtrates from Fusarium solani, the causal agent of sudden death syndrome of soybean. Plant Dis. 80:922-927.

18. Killebrew, J. F., Roy, K. W., and Abney, T. S. 1993. Fusaria and other fungi on soybean seedlings and roots of older plants and interrelationships among fungi, symptoms and soil characteristics. Can. J. Plant Pathol. 15:139146.

19. Killebrew, J. F., Roy, K. W., Lawrence, G. W., McLean, K. S., and Hodges, H. H. 1988. Greenhouse and field evaluation of Fusarium solani pathogenicity to soybean seedlings. Plant Dis. 72:1067-1070.

20. Kraft, J. M., Burke, D. W., and Haglund, W. A. 1981. Fusarium diseases of beans, peas, and lentils. Pages 142-156 in: Fusarium: Diseases, Biology, and Taxonomy. P. E. Nelson, T. A. Toussoun, and R. J. Cook, eds. Pennsylvania State University, University Park.

21. Lewis, J. A., and Papavizas, G. C. 1977.
Effect of plant residues on chlamydospore germination of Fusarium solani f. sp. phaseoli and on Fusarium root rot of beans. Phytopathology 67:925-929.

22. Melgar, J., and Roy, K. W. 1994. Soybean sudden death syndrome: Cultivar reactions to noculation in a controlled environment and host range and virulence of causal agent. Plant Dis. 78:265-268.

23. Melgar, J., Roy, K. W., and Abney, T. S. 1994. Sudden death syndrome of soybean: Etiology, symptomatology, and effects of irrigation and Heterodera glycines on incidence and severity under field conditions. Can. J. Bot. 72:16471653.

24. Messiaen, C. M, and Cassini, R. 1981. Taxonomy of Fusarium. Pages 427-445 in: Fusarium: Diseases, Biology, and Taxonomy. P. Nelson, T. A. Toussoun, and R. J. Cook, eds. Pennsylvania State University, University Park.

25. Miller, W. A., and Roy, K. W. 1982. Mycoflora of soybean leaves, pods, and seeds. Can. J. Bot. 60:2716-2723

26. Morgan-Jones, G., Gintis, B. O., and Rodriquez-Kabana, R. 1981. Fungal colonization of Heterodera glycines cysts in Arkansas, Florida, Mississippi, and Missouri soils. Nematropica 11:155-163.

27. Nelson, P. E., Toussoun, T. A., and Marasas, W. F. O. 1983. Fusarium Species: An Illustrated Manual for Identification. Pennsylvania State University, University Park.

28. O'Donnell, K., and Gray, L. E. 1995. Phylogenetic relationships of the soybean sudden death syndrome pathogen Fusarium solani f. sp. phaseoli inferred from rDNA sequence data and PCR primers for its identification. Mol. Plant-Microbe Interact. 8:709-716.

29. Pascoe, I. G., Nancarrow, R. J., and Copes, C. J. 1984. Fusarium tabacinum on tomato and other hosts in Australia. Trans. Br. Mycol. Soc. 82:343-345.

30. Reinking, O. A. 1950. Fusarium strains causing pea and bean root rot. Phytopathology 40:664-683.

31. Rossman, A. Y. 1993. Holomorphic hypocrealean fungi: Nectria sensu stricto and teleomorphs of Fusarium. Pages 149-160 in: The Fungal Holomorph: Mitotic, Meiotic, and Pleomorphic Speciation in Fungal Systemetics. D. R. Reynolds and J. W. Taylor, eds. $\mathrm{CAB}$ International, Wallingford, England.

32. Roy, K. W., Abney, T. S., and Patel, M. V. 1993. Soybean SDS in the Midwest and South: Disease incidence and association of Fusarium solani with roots and with cysts of Heterodera glycines. (Abstr.) Phytopathology 83:467.

33. Roy, K. W., Lawrence, G. W., Hodges, H. H., McLean, K. S., and Killebrew, J. F. 1988. Etiology of sudden death syndrome of soybean. Proc. South. Soybean Dis. Work. Conf. 15:30.

34. Roy, K. W., Lawrence, G. W., Hodges, H. H., McLean, K. S., and Killebrew, J. F. 1989. Sudden death syndrome of soybean: Fusarium solani as incitant and relation of Heterodera glycines to disease severity. Phytopathology 79:191-197.

35. Roy, K. W., Lawrence, G. W., and McLean, K. S. 1989. Isolation and identification of Fusarium solani, the cause of sudden death syndrome of soybean. Plant Diagn. Quart. 10:17-27

36. Roy, K. W., Lawrence, G. W., McLean, K. S., Hodges, H. H., and Hirrel, M. C. 1989. Sudden death syndrome of soybean: The causal agent. Pages 1290-1295 in: Proc. World Soybean Res. Conf. IV. Buenos Aires, Argentina. A. J. Pascale, ed. Westview Press, Boulder, CO.
37. Roy, K. W., Moore, W. F., and Abney, T. S. 1991. Diagnosis of sudden death syndrome of soybean. Plant Diagn. Quart. 12:166-168.

38. Roy, K. W., and Ratnayake, S. 1996. Asexual reproduction and survival of Fusarium solani in soybean fields. (Abstr.) Phytopathology 86:S97.

39. Roy, K. W., and Van Etten, H. 1993. Further characterization of Fusarium solani strains from soybean. Page 143 in: Proc. Congr. Plant Pathol., 6th. Montreal, Quebec.

40. Rupe, J. C. 1989. Frequency and pathogenicity of Fusarium solani recovered from soybeans with sudden death syndrome. Plant Dis. 73:581-584.

41. Rupe, J. C., Becton, C. M., Williams, K. J., and Yount, P. 1996. Isolation, identification, and evaluation of fungi for the control of sudden death syndrome of soybean. Can. J. Plant Pathol. 18:1-6.

42. Rupe, J. C., Correll, J. C., and Yount, P. 1993. Differentiation of the soybean sudden death syndrome pathogen, Fusarium solani, from other isolates of $F$. solani based on cultural morphology and mitochondrial DNA RFLPs. (Abstr.) Phytopathology 83:1423.

43. Rupe, J. C., Gbur, E. E., and Marx, D. M 1991. Cultivar response to sudden death syndrome of soybean. Plant Dis. 75:47-50.

44. Rupe, J. C., Sabbe, W. F., Robbins, R. T., and Gbur, E. E. 1993. Soil and plant factors associated with sudden death syndrome of soybean. J. Prod. Agric. 6:218-221.

45. Schroth, M. N., and Hendrix, F. F., Jr. 1962 Influence of nonsusceptible plants on the survival of Fusarium solani f. phaseoli in soil Phytopathology 52:906-909.

46. Schuerger, A. C., and Mitchell, D. J. 1992 Effects of temperature, hydrogen ion concentration, humidity, and light quality on disease caused by Fusarium solani f. sp. phaseoli in Vigna radiata. Can. J. Bot. 70:1798-1808.

47. Snyder, W. C. 1970. Means of (Fusarium) existence in soil. Pages 3-6 in: Nature of the Influence of Crop Residues on Fungus-Induced Root Diseases. R. J. Cook and R. D. Watson, eds. Wash. Agric. Exp. Stn. Bull. 716.

48. Snyder, W. C., and Hansen, H. N. 1941. The species concept in Fusarium with reference to section Mortiella. Am. J. Bot. 28:738-742.

49. Snyder, W. C., Schroth, M. N., and Christou, T. 1959. Effect of plant residues on root rot of bean. Phytopathology 49:755-756.

50. Stephens, P. A., Nickell, C. D., and Kolb, F. L. 1993. Genetic analysis of resistance to Fusarium solani in soybean. Crop Sci. 33:929-930.

51. Stephens, P. A., Nickell, C. D., and Lim, S. M. 1993. Sudden death syndrome development in soybean cultivars differing in resistance to Fusarium solani. Crop Sci. 33:63-66.

52. Stephens, P. A., Nickell, C. D., Moots, C. K., and Lim, S. M. 1993. Relationship between field and greenhouse reactions of soybean to Fusarium solani. Plant Dis. 77:163-166.

53. Weimer, J. L., and Harter, L. L. 1926. Root rot of bean in California caused by Fusarium martii phaseoli Burk. and F. aduncisporum n. sp. J. Agric. Res. 32:311-319.

54. Yang, S. M., and Hagedorn, D. J. 1967. Cultural and pathogenicity studies of induced variants of bean and pea root rot Fusarium species. Phytopathology 58:639-643.

55. Zambolim, L., Schenck, N. C., and Mitchell, D. J. 1983. Inoculum density, pathogenicity, and interactions of soybean root-infecting fungi. Phytopathology 73:1398-1402.

56. Zazzerini, A., and Tosi, L. 1987. New sunflower disease caused by Fusarium tabacinum. Plant Dis. 71:1043-1044. 